\title{
IN VITRO AND IN VIVO EVALUATION OF PHARMACOLOGICAL ACTIVITES OF POUZOLZIA SANGUINEA
}

\author{
MQ Ahsan ${ }^{\star 1,2,4}$, MT Alam ${ }^{1}$, MMU Chowdhury ${ }^{1}$, MT Nasim ${ }^{2,3}$ and SMS Islam ${ }^{4}$ \\ 1Department of Pharmacy, Southern University Bangladesh, Chittagong, Bangladesh \\ ${ }^{2}$ Centre for Health, Agriculture and Socio-economic Advancements (CHASA), Lalmonirhat, Bangladesh \\ ${ }^{3}$ Faculty of Life Sciences, School of Pharmacy and Medical Sciences, University of Bradford, UK \\ 4Institute of Biological Sciences, University of Rajshahi, Rajshahi-6205, Bangladesh
}

\begin{abstract}
Pouzolzia sanguinea grows in tropical and sub-tropical regions of Bangladesh, used for a variety of purposes including pain, rheumatoid kidney diseases in traditional medicine. The crude ethanolic leaf extract of $P$. sanguinea with its different fractions (ethanol, n-hexane, and chloroform) was investigated for phytochemical constituents, in vitro antioxidant, anti-inflammatory effects, in-vivo analgesic and antipyretic activities. Preliminary phytochemical constituents were identified by chemical group test. $P$. sanguinea fractionated extracts contain alkaloids, glycosides, tannins, flavonoids, saponins, gums, and amides. Antioxidant activity test was performed by both qualitative (TLC and Rf value) and quantitative tests (inhibition of DPPH free radical scavenging). Extracts exhibited significant $(p<0.001, p$ $<0.0001$ ) inhibition of DPPH free radical scavenging activity as compared to the standard drug ascorbic acid at similar doses. In vitro anti-inflammatory activity was determined by protein denaturation of egg albumin method. The percent inhibition of protein denaturation in the experiment of ethanol extract was found significantly higher $(\mathrm{p}<0.0001)$ compared with chloroform and $n$-hexane extracts. In addition, in vivo analgesic and antipyretic effects were determined in mice by acetic acid-induced writhing and yeast-induced pyrexia methods. The ethanol extracts of $P$. sanguinea exhibited inhibition of writhing reflex on mice by $71.58 \%$ at the dose of $500 \mathrm{mg} / \mathrm{kg}$ body weight which had greater analgesic activity than other n-hexane and chloroform extracts. In the anti-pyretic test, fractional extracts ethanol, chloroform, and n-hexane at a dose of $500 \mathrm{mg} / \mathrm{kg}$ body weight significantly $(\mathrm{p}<0.05)$ decreased pyrexia in mice up to $3 \mathrm{~h}$ as compared with the positive control paracetamol drug at a dose of $150 \mathrm{mg} / \mathrm{kg}$ body weight. In our in vitro and in vivo study models, it is evident that Pouzolzia sanguinea fractionated extracts showed significant antioxidant, anti-inflammatory, analgesic, and antipyretic activities.
\end{abstract}

Key words: Analgesic, Antipyretic, Anti-inflammatory, Phytochemical screening, Pouzolzia sanguinea

\section{Introduction}

Pouzolzia (Urticaceae family) is a genus of flowering plants in the nettle family (Wilmot-Dear et al. 2004). There are about 35 species grown in tropical and sub-tropical countries (Kravtsova et al. 2003). The genus was named for French botanist and plant collector Pierre Marie Casimir de Pouzolz (Pouzolz 2012). $P$. sanguinea (Blume) Merr (Urticaceae family) is an evergreen flowering shrub that grows widely in warm climates and is found in several countries in Asia, including India, China, Thailand, Vietnam, and Bangladesh (Nhung et al. 2020). P. elegans has been recognized here at varietal rank under $P$. sanguinea because there are intermediates in leaf shape and leaf margin characters in Taiwan, Yunnan, and Nepal, and there is only

*Author for correspondence: shahinul68@gmail.com, qamrul2010@southern.edu.bd 
partial geographic separation from $P$. sanguinea (Merrill and Elmer 1921). The genus is used for medicinal herbs as well as culinary purposes in various African and Asian countries (Grubben and Denton 2004). Recent reports on the pharmacological activities indicated that the crude plant extracts had antiinflammatory (Siriwatanametanon et al. 2010), antibacterial (Rabe and van Staden 1997), antioxidant (Yadav et al. 2012), and anti-snake venom activities (Ahmed et al. 2010). The species, $P$. bennettiana of methanolic extracts reported phenolic, flavonoids compounds and antioxidant activities (Payum et al. 2015).

The minerals, antioxidants and nutrients composition of Pouzolzia hirta rhizomes were determined (Prasad et al. 2014). The rhizomes of this plant have also been found rich in minerals such as $\mathrm{Na}, \mathrm{K}, \mathrm{Ca}, \mathrm{S}, \mathrm{P}, \mathrm{Fe}, \mathrm{Mn}$, $\mathrm{Cu}$ and $\mathrm{Zn}$. The plants rhizomes powder mixed with wheat and maize flours are used traditionally to make chapatti. The species, $P$. indica is used as remedy for the ailments in female infertility, cancer, and inflammation and as insecticide (Srisapoomi et al. 2008). An isoflavone compound of lanceolone of this plant species has been isolated (Sayeed et al. 2003). In addition, the antiproliferative effect of the methanolic part of this plant has exhibited on NB4 and HT93A acute leukemic cells, with $I_{50}$ values of $28.5 \mathrm{mg} / \mathrm{ml}$ and 49.8 $\mathrm{mg} / \mathrm{ml}$, respectively (Upratya et al. 2008). The cytotoxic activity of $P$. indica methanol extract has been shown to induce apoptosis of both NB4 and HT93A cell lines (Chanyapat et al. 2013).

Aerial parts of another species, $P$. zeylanica have been used as a folk medicine for the treatment of skin and soft tissue infections, including skin abscesses, gangrenous ulcers, dysentery, syphilis, sores, boils, gonorrhea, in Fujian Provinces for over 2000 years (Dangol et al. 1991, Van Sam et al. 2008). It has been reported that the methanol extracts of $P$. zeylanica had antioxidant, anti-inflmmatory, cytotoxic, antimicrobial potential and analgesic activities (Hossain MS et al. 2016). The leaves of $P$. sanguinea are edible and are used in traditional medicines to treat diarrhea, ulcers, and inflammation (Chi 1997). No work has been reported on anti-oxidant, anti-inflammatory, antipyretic and analgesic activity. The present work has evaluated the in vitro and in vivo pharmacological activities of $P$. sanguinea.

\section{Materials and Methods}

\section{Chemicals}

Various chemicals and solvents (DPPH, ethanol, chloroform, n-hexane etc.) used in this study were of analytical grade and purchased from Merck, Germany. Standard drugs such as loperamide, diclofenac sodium, paracetamol and acetyl salicylic acid were obtained from Square Pharmaceuticals Ltd., Dhaka, Bangladesh.

\section{Selection and identification of the plant}

Mature leaves of $P$. sanguinea were selected for study. The plants were collected from forest area, Sithakundo, Chittagong, Bangladesh in 2020. Taxonomical identification of this plant was carried out by the experts of Bangladesh Forest Research Institute Herbarium (BFRIH), Chittagong. The herbarium sheet was prepared following the standard procedure and specification suggested by the expert of the institute. The sheet was signed by the taxonomist and preserved in Pharmacognosy Laboratory, Department of Pharmacy, Southern University, Chittagong, Bangladesh. 


\section{Drying and grinding}

Collected plants were dried by shade drying at temperature not exceeding $50^{\circ} \mathrm{C}$. Then these were grounded into a coarse powder with the help of a suitable grinder. The powder was stored in an airtight container and kept in a cool, dark and dry place until extraction and analysis commenced.

\section{Ethanol extraction on Soxhlet apparatus}

For hot extraction, about $140 \mathrm{~g}$ powder of the plant was subjected to $1000 \mathrm{ml}$ of absolute ethanol (96\%) in a Soxhlet Apparatus (Quickfit, England). The obtained extract was collected, filtered and made to evaporate the solvent below $60^{\circ} \mathrm{C}$. After evaporation of the solvent, a gummy concentrate was obtained which was designated as hot ethanolic crude extracts.

\section{Fractionation of the crude ethanolic extracts}

Solvent-solvent partitioning was done using the protocol design by Kupcha (1973) and modified by Wagenen et al. (1993). The ethanolic extracts of $P$. sanguinea (together $15 \mathrm{~g}$ ) were dissolved in a mixture of 1:4 ethanol-water solvent and then fractionated using fractionating column with n-hexane and subsequently with chloroform. Fractionation was done by using $10 \mathrm{ml}$ solvent each time until $150 \mathrm{ml}$-hexane was used and each time after vigorous shaking the mixture was allowed to stand. Solvent layers were separated and the lower layer was decanted. Similarly extraction was carried out by chloroform. The remaining extract was used as fraction of ethanol. The obtained extract was collected, filtered and made to evaporate the solvent below $50^{\circ} \mathrm{C}$. After evaporation of the solvent it rendered a gummy concentrate. The gummy concentrate was weighed and taken in properly labeled clean air tight closure container and stored at $4^{\circ} \mathrm{C}$ (Bhal et al. 2003).

\section{Experimental animals}

Swiss albino mice of both sexes (male and female), at the age of 6-7 weeks, weighing between 25-30 g, were collected from the Bangladesh Council of Scientific and Industrial Research (BCSIR), Chittagong for in vivo experiment. All the mice were maintained under standard laboratory conditions of temperature at 25.0 $\pm 1.0^{\circ} \mathrm{C}$, relative humidity: $55-65 \%$ and $12 \mathrm{~h}$ light $12 \mathrm{~h}$ dark cycle and water ad libitum. All protocols for animal were followed by the Institutional Animal Ethics Committee and the appropriate measures were taken to minimize the pain or discomfort of animals (Zimmermann 1983). The animals were fasted overnight but allowed fresh water ad libitum. This study was approved by ethical research committee of Institutional Animal, Medical Ethics, Biosafety and Biosecurity Committee (IAMEBBC) for Experimentations on Animal, Human, Microbs and Living Natural Sources at the Institute of Biological Sciences, University of Rajshahi, Bangladesh.

\section{Preliminary phytochemical screening}

The freshly prepared crude extract was qualitatively tested for the presence of chemical constituents. Phytochemical screenings of the extracts were performed using the following reagents and chemicals such as alkaloids with Dragendorff's reagents, flavonoids with the use of alchohol and $\mathrm{HCl}$; tannins with ferric chloride, glacial acetic acid and potassium dichromate solutions and saponins with ability to produce stable foam and steroids and glycosides with Burchard and Salkowski reagent. Gum was tested using molish reagent and concentrated sulfuric acid; reducing sugars with Benedict's reagent. These were identified by characteristic color changes using standard procedures (Ghani 2005). 


\section{Tests for antioxidant activity}

\section{Qualitative assay}

Preliminary phytochemical screening of the ethanol extracts of $P$. sanguinea were investigated by thin layer chromatography. TLC is a technique with large applicability in the fields of plant material analysis. In the qualitative antioxidant test, the bleaching of DPPH results resolve of the bands and then the color changed (yellow with purple background) for confirmation of antioxidant property and determined Rf value by using following formula-

$$
\text { Rf value }=\frac{\text { Distanced travelled by solute }}{\text { Distance travelled by solvent }}
$$

\section{Quantitative assay (DPPH free radical scavenging activity)}

The stable DPPH free-radical scavenging activity was determined using the modified method described (Chang et al. 2001). The method is based on the reduction of ethanolic DPPH solution in the presence of a hydrogen donating antioxidant, due to the formation of the non-radical form DPPH-H by reaction. $0.1 \mathrm{ml}$ of ethanol extract of $P$. sanguinea (EEPS), n-hexane extract of $P$. sanguinea (NEPS) and chloroform extract of $P$. sanguinea (CEPS), at various concentrations $(20 \mu \mathrm{g} / \mathrm{ml}$ to $100 \mu \mathrm{g} / \mathrm{ml}$ ) was added up to $3 \mathrm{ml}$ of $0.004 \%$ methanol solution of DPPH. All the reaction tubes were kept in dark except control (blank) tubes for 30 minutes. After 30 minutes, absorbance of the resulting solution was measured against a blank at $517 \mathrm{~nm}$ (Sultana et al. 2018). The percentage DPPH radical scavenging activities (\% of SCV) by comparing the results of the test with the control (not treated with extract) using following formula-

$$
\% \text { of SCV }=\frac{(\mathrm{Ao}-\mathrm{At})}{\mathrm{Ao}} \times 100
$$

Where, $\mathrm{SCV}=$ Radical scavenging activity, $\mathrm{AO}=$ Absorbance of the control and $A_{t}=$ Absorbance of the test (extracts / standard).

\section{In vitro anti-inflammatory activity}

The reaction mixture $(5.0 \mathrm{ml}$ ) consisted of $0.2 \mathrm{ml}$ of egg albumin solution (from fresh hen's egg), $2.8 \mathrm{ml}$ of phosphate-buffered solution (PBS, pH 6.4) and $2 \mathrm{ml}$ of varying concentrations $(10 \mu \mathrm{g} / \mathrm{ml}$ to $160 \mu \mathrm{g} / \mathrm{ml})$ of fractional extracts. A similar volume of double-distilled water served as the control (blank). Next, the mixtures were incubated at $37 \pm 2^{\circ} \mathrm{C}$ in a BOD incubator for $15 \mathrm{~min}$ and then heated at $70^{\circ} \mathrm{C}$ for five minutes. After cooling, their absorbance was measured at $660 \mathrm{~nm}$ by using the vehicle as a blank. Acetyl salicylic acid was used as the similar concentrations for reference drug (Shinde et al. 1999). The percentage inhibition of protein denaturation was calculated by using the following formula-

$$
\% \text { Inhibition of protein denaturation }=\left(1-\frac{\mathrm{Vt}}{\mathrm{Vc}}\right) \times 100
$$

Where, $\mathrm{V}_{\mathrm{t}}=$ absorbance of the standard/test sample; $\mathrm{Vc}=$ absorbance of control. 


\section{In vivo analgesic activity}

\section{Acetic acid-induced writhing test}

Muscle contractions were induced in mice by intra peritoneal injection of $0.7 \%$ solution of acetic acid (10 $\mathrm{ml} / \mathrm{kg}$ ). For test groups, $500 \mathrm{mg} / \mathrm{kg}$ of leaves extracts of EEPS, NEPS and CEPS were selected. For standard $(25 \mathrm{mg} / \mathrm{kg}), 0.025 \mathrm{~g}$ of Diclofenac-Na taken and a suspension of $10 \mathrm{ml}$ were made and for control group, 50 $\mathrm{mg}$ of Tween-80 was added with double distilled water (DDW) to $5 \mathrm{ml}$. For preparation of $0.7 \%$ acetic acid solution, $0.7 \mathrm{ml}$ glacial acetic acid was mixed with DDW to $100 \mathrm{ml}$ (Collier et al. 1968).

\section{In vivo antipyretic activity}

In this test, antipyretic activity of EEPS, CEPS and NEPS was evaluated on Swiss albino mice (25-30 g) of either sex. The animals were divided into five groups, each group containing three mice. The normal body temperature of each mouse was recorded using digital thermometer and then pyrexia was induced in all mice by injecting 10\% aqueous suspension of Brewer's yeast (10 ml/kg body weight). All groups were fasted overnight but free accesses to drinking water were provided. At the $18 \mathrm{~h}$ after yeast injection, the vehicle (double distilled water), standard drug and extracts were administered into different groups. Double distilled water at dose of $10 \mathrm{ml} / \mathrm{kg}$ body weight was administered orally to the control groups (blank) of animals and paracetamol at dose of $150 \mathrm{mg} / \mathrm{kg}$ body weight was administered orally to standard group of animals (Adams et al. 1968). The $P$. sanguinea plant extracts were administered orally at a dose of $500 \mathrm{mg} / \mathrm{kg}$ of body weight. Rectal temperature was recorded by digital thermometer at 0, 1, 2 and $3 \mathrm{~h}$ after drug administration.

\section{Statistical analysis}

The data were presented as mean standard error mean $( \pm S E M)$. The statistical data were analyzed by Microsoft Excel, t-test for multiple comparisons. For the comparison between two groups, student's t-test was employed. The significant difference was considered at $p<0.05, p<0.01, p<0.001$ and $p<0.0001$ levels.

\section{Results and Discussion}

\section{Preliminary phytochemical screening}

Preliminary phytochemical screening of $P$. sanguinea revealed that all three fractional extracts contained alkaloids, glycosides, steroids, tannins, flavonids, saponins, gums and amides except chloroform extracts where flavonoids were absent. None of the extracts contained reducing sugar.

Table 1. Presumed chemical groups test for the plant

\begin{tabular}{|c|c|c|c|c|c|c|c|c|c|}
\hline Chemical groups & 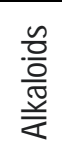 & 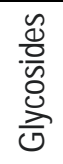 & $\begin{array}{l}\frac{n}{0} \\
\frac{0}{D} \\
\dot{ \pm} \\
\dot{n}\end{array}$ & 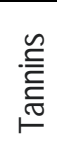 & $\begin{array}{l}\frac{0}{0} \\
\frac{0}{0} \\
\frac{0}{0} \\
\frac{\pi}{\square} \\
\end{array}$ & 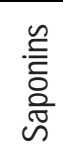 & 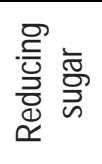 & $\stackrel{\mathscr{N}}{\sum_{\mathcal{J}}^{J}}$ & $\frac{\mathscr{d}}{\frac{O}{E}}$ \\
\hline EEPS & + & + & + & + & + & + & - & + & + \\
\hline CEPS & + & + & - & + & - & + & - & + & + \\
\hline NEPS & + & - & + & + & + & + & - & + & + \\
\hline
\end{tabular}

EEPS $=$ Ethanol extract of $P$. sanguinea, CEPS $=$ Chloroform extract of $P$. sanguinea, NEPS $=$ n-hexane extract of $P$. sanguinea, $+=$ indicates present and $-=$ indicates absent. 


\section{Tests for antioxidant activity}

\section{Qualitative assay}

TLC is a technique with large applicability in the fields of plant material analysis. When the plates were viewed under UV detector a lot of colored and fluorescent positive components were found in short (254 nm) and long wavelengths $(360 \mathrm{~nm})$ respectively, which indicated the presence of UV positive materials in the plant extract and they were marked. For the determination of Rf value, the highest number Rf value of fractional extracts found in non-polar solvents as shown in Table 2. EEPS extracts in three different solvents showed greatest number of Rf value than CEPS and NEPS which indicated that compounds had low affinity to the stationary phase (TLC plates).

Table 2. Rf values of crude extract

\begin{tabular}{llll}
\hline Solvent system & Rf value of EEPS & Rf value of CEPS & Rf value of NEPS \\
\hline Polar & $0.85 \pm 0.006$ & $0.73 \pm 0.019$ & $0.71 \pm 0.011$ \\
Medium polar & $0.86 \pm 0.014$ & $0.78 \pm 0.007$ & $0.68 \pm 0.007$ \\
Non-polar & $0.90 \pm 0.019$ & $0.82 \pm 0.003$ & $0.61 \pm 0.007$ \\
\hline
\end{tabular}

EEPS $=$ Ethanol extract of $P$. sanguinea, CEPS $=$ Chloroform extract of $P$. sanguinea, NEPS $=n$-hexane extract of $P$. sanguinea and SEM $=$ Standard error mean, $\mathrm{n}=3$, each group.

\section{Quantitative assay (DPPH free radical scavenging activity)}

We have investigated the antioxidant activities of the extracts by determining free radical scavenging activities. The various concentrations of fractional extracts $(20 \mu \mathrm{g} / \mathrm{ml}$ to $100 \mu \mathrm{g} / \mathrm{ml})$ were increased with increased antioxidant activities as compared with standard drug of ascorbic acid. We found that all three extracts tested showed moderate antioxidant activities in a dose-dependent manner. Among them, EEPS showed most significant $\left({ }^{*} p<0.001,{ }^{* *} p<0.0001\right)$ anti-oxidant activities than CEPS and NEPS. However, CEPS and NEPS similarly increased \% inhibition of DPPH as the concentration increased which shown in Table 3. This study demonstrates that the fractionated leaf extracts reduced level of DPPH because of presence of alkaloids, saponins, tannins, glycoside which may be represented as an indicator of potential antioxidant activity. 
Table 3. Determination of Free radical scavenging activity by DPPH

\begin{tabular}{|c|c|c|c|}
\hline Test group & Concentration $(\mu \mathrm{g} / \mathrm{ml})$ & $\begin{array}{c}\text { Mean absorbance } \\
(\text { Mean } \pm \text { SEM })\end{array}$ & $\%$ Inhibition of DPPH \\
\hline Control (blank) & 0 & $0.433 \pm 0.001$ & - \\
\hline \multirow{5}{*}{ ASC (standard) } & 20 & $0.219 \pm 0.002^{* * *}$ & 49.03 \\
\hline & 40 & $0.188 \pm 0.002^{\text {*k* }}$ & 56.53 \\
\hline & 60 & $0.136 \pm 0.001^{* * t *}$ & 68.61 \\
\hline & 80 & $0.098 \pm 0.003^{* \star *}$ & 77.46 \\
\hline & 100 & $0.072 \pm 0.003^{* \star *}$ & 83.30 \\
\hline \multirow{5}{*}{ EEPS } & 20 & $0.241 \pm 0.002^{* \star \star}$ & 44.35 \\
\hline & 40 & $0.224 \pm 0.002^{* * *}$ & 48.15 \\
\hline & 60 & $0.183 \pm 0.003^{\star \star *}$ & 57.69 \\
\hline & 80 & $0.159 \pm 0.006^{* *}$ & 63.31 \\
\hline & 100 & $0.116 \pm 0.001^{\star *}$ & 73.15 \\
\hline \multirow{5}{*}{ CEPS } & 20 & $0.277 \pm 0.005^{* *}$ & 35.92 \\
\hline & 40 & $0.244 \pm 0.003^{*}$ & 43.53 \\
\hline & 60 & $0.224 \pm 0.005^{*}$ & 48.15 \\
\hline & 80 & $0.191 \pm 0.004^{* *}$ & 55.84 \\
\hline & 100 & $0.152 \pm 0.002^{* \star \star}$ & 64.92 \\
\hline \multirow{5}{*}{ NEPS } & 20 & $0.341 \pm 0.003^{*}$ & 21.23 \\
\hline & 40 & $0.306 \pm 0.004^{* *}$ & 29.38 \\
\hline & 60 & $0.263 \pm 0.0007^{* \star *}$ & 39.30 \\
\hline & 80 & $0.199 \pm 0.0004^{* * *}$ & 54.00 \\
\hline & 100 & $0.179 \pm 0.001^{\star \star \star}$ & 58.69 \\
\hline
\end{tabular}

ASC $=$ Ascorbic acid, EEPS $=$ Ethanol extract of $P$. sanguinea, $\mathrm{CEPS}=$ Chloroform extract of $P$. sanguine, NEPS $=$ extract of $P$. sanguine, $n=3$, each group, SEM = Standard error and ${ }^{*} p<0.01{ }^{* *} p<0.001$, ${ }^{* * *} \mathrm{p}<0.0001$ significant compared to control.

\section{In vitro anti-inflammatory effect}

The in vitro anti-inflammatory effect of $P$. sanguinea was evaluated against protein denaturation of egg albumin. The percent inhibition of protein denaturation of EEPS was moderate $62.57 \%\left({ }^{*} \mathrm{p}<0.001\right)$ at a concentration $160 \mu \mathrm{g} / \mathrm{ml}$ compared with those of NEPS and CEPS extracts. The standard drug of acetyl salicylic acid showed maximum inhibition of $79.08 \%\left({ }^{*} p<0.01\right)$ at the same concentration and the results 
have been summarized in Table 4. The inflammation is caused by denaturation of proteins. The percent inhibition of protein denaturation activities of the EEPS, NEPS and CEPS demonstrated mild to moderate anti-inflammatory activity at various concentrations tested. The presence of alkaloids, flavonoids, tannins and phenols in the extracts may inhibit prostaglandin synthetize which has been shown for its anti-inflammatory effects (Patel et al. 2012).

Table 4. Spectrophotometric determination of anti-inflammatory activity of fractional extracts of $P$. sanguinea

\begin{tabular}{|c|c|c|c|}
\hline Test group & $\begin{array}{c}\text { Concentration } \\
(\mu \mathrm{g} / \mathrm{ml})\end{array}$ & $\begin{array}{c}\text { Absorbance mean } \\
(660 \mathrm{~nm}) \pm \mathrm{SEM}\end{array}$ & $\%$ MIPD \\
\hline \multirow[t]{3}{*}{ Control (blank) } & 0 & $1.790 \pm 0.0070$ & - \\
\hline & 10 & $1.157 \pm 0.032^{* k *}$ & 35.32 \\
\hline & 20 & $0.886 \pm 0.017^{\star \star \star}$ & 50.46 \\
\hline \multirow[t]{4}{*}{ ASA (standard) } & 40 & $0.706 \pm 0.004^{* \star *}$ & 60.52 \\
\hline & 80 & $0.494 \pm 0.004^{* *}$ & 72.40 \\
\hline & 160 & $0.374 \pm 0.0004^{*}$ & 79.08 \\
\hline & 10 & $1.506 \pm 0.014^{*}$ & 15.82 \\
\hline \multirow[t]{5}{*}{ EEPS } & 20 & $1.376 \pm 0.010^{*}$ & 23.09 \\
\hline & 40 & $1.133 \pm 0.010^{\text {** }}$ & 36.68 \\
\hline & 80 & $0.095 \pm 0.004^{* *}$ & 47.11 \\
\hline & 160 & $0.067 \pm 0.007^{\text {** }}$ & 62.57 \\
\hline & 10 & $1.610 \pm 0.010^{*}$ & 10.05 \\
\hline \multirow[t]{5}{*}{ CEPS } & 20 & $1.553 \pm 0.014^{*}$ & 13.22 \\
\hline & 40 & $1.296 \pm 0.004^{* *}$ & 27.56 \\
\hline & 80 & $0.967 \pm 0.010^{\text {** }}$ & 45.99 \\
\hline & 160 & $0.763 \pm 0.017^{* *}$ & 57.35 \\
\hline & 10 & $1.576 \pm 0.010^{*}$ & 11.91 \\
\hline \multirow[t]{4}{*}{ NEPS } & 20 & $1.420 \pm 0.018^{*}$ & 20.67 \\
\hline & 40 & $1.116 \pm 0.010^{* *}$ & 37.61 \\
\hline & 80 & $0.913 \pm 0.017^{* *}$ & 48.97 \\
\hline & 160 & $0.726 \pm 0.010^{* * *}$ & 59.40 \\
\hline
\end{tabular}

ASA $=$ Acetyl salicylic acid, EEPS $=$ Ethanol extract of $P$. sanguinea, CEPS $=$ Chloroform extract of $P$. sanguine, NEPS = extract of $P$. sanguine, MIDP = Mean inhibition protein denaturation, SEM = Standard error mean, $n=3$, each group and ${ }^{*} p=<0.01,{ }^{* *} p=<0.001,{ }^{* * *} p=<0.0001$ significant compared to control. 


\section{Analgesic activity}

In in vivo analgesic activity test, the EEPS, CEPS and NEPS reduced significantly the number of writhing. EEPS, CEPS and NEPS showed significant protection in analgesic test at the dose of $500 \mathrm{mg} / \mathrm{kg}$ body weight and the activities exhibited were $71.58 \%$ (** $\left.{ }^{*}<0.05\right), 57.37 \%$, ( $\left.{ }^{*}<<0.01\right)$ and $46.45 \%(* p<0.05)$, respectively. The standard drug DS (diclofenac-sodium) exerted $78.68 \%(* *<<0.05)$ activity at the dose of 25 $\mathrm{mg} / \mathrm{kg}$ body weight (Table 5).

Our EEPS, CEPS and NEPS extracts showed significant $\left({ }^{\star} p<0.05,{ }^{* \star} p<0.01\right)$ analgesic activity. Acetic acid induces an increased level of PGE2 and PGF2 in the peritoneal fluid, which are responsible induction of pain (Derardt et al. 1980, Sulaiman et al. 2008). Various analgesic drugs like ibuprofen, diclonefac sodium and aspirin have been reported that inhibit acid induced writhing by inhibition of prostaglandin synthesis (Ishfaq et al. 2004). We speculate that the analgesic activities of EEPS, CEPS and NEPS extracts might be mediated through the activation of PGE2 andPGF2. Further studies are required to confirm this speculation.

Table 5. Effect of crude extracts on acetic acid induced writhing in mice.

\begin{tabular}{lccc}
\hline Test group & Total writhing & \% of Writing & \% Protection \\
\hline Control & 305.00 & 100 & - \\
DS (Standard) & 65.00 & 21.31 & $78.68^{* *}$ \\
EEPS & 86.66 & 28.41 & $71.58^{* *}$ \\
CEPS & 130.00 & 42.62 & $57.37^{\star}$ \\
NEPS & 163.33 & 53.55 & $46.45^{* *}$ \\
\hline
\end{tabular}

DS = Diclofenac Sodium, EEPS $=$ Ethanol extract of $P$. sanguinea, CEPS $=$ Chloroform extract of $P$. sanguine, NEPS $=$ extract of $P$. sanguine, $n=3$, each group and ${ }^{*} p<0.05,{ }^{* *} p<0.01$ significant compared to control.

\section{Result of anti-pyretic activity}

The effect of EEPS, CEPS and NEPS on mice has been presented in Table 6 . In this test, all the extracts at a dose of $500 \mathrm{mg} / \mathrm{kg}$ body weight better decreased pyrexia in mice up to $3 \mathrm{~h}$. Throughout the experiment, the EEPS, CEPS and NEPS extracts significantly $\left({ }^{*} \mathrm{p}<0.05\right)$ reduced temperature from $101.0^{\circ} \mathrm{F}$ to $97.90^{\circ} \mathrm{F}$, $101.2^{\circ} \mathrm{F}$ to $97.6^{\circ} \mathrm{F}, 101.3^{\circ} \mathrm{F}$ to $97.61^{\circ} \mathrm{F}$ respectively and exhibited a better antipyretic activity in comparison to the positive control paracetamol showed very well antipyretic activity starting after 1st hour of administration up to next $3 \mathrm{~h}$.

The antipyretic activity test, pyrexia is occurred by brewer's yeast induces through subcutaneous injection which increased the synthesis of prostaglandin. The EEPS gradually reduced body temperature in our experimental animal (Swiss albino mice). Most of the NSAIDs inhibit prostaglandin synthesis which shows the antipyretic activity. The extracts exhibited anti-pyretic action as that of paracetamol which inhibited synthesis prostaglandin can be achieved by blocking the cyclooxygenase enzyme activity (Hossain et al. 
2016). There are many mediators responsible for pyrexia and the inhibition of these mediators is the antipyretic effect. Thus extracts might have interfered with the release of prostaglandins.

Table 6. Effect of on Brewer's yeast Pouzolzia sanguinea induced pyrexia in mice

\begin{tabular}{|c|c|c|c|c|c|c|}
\hline \multirow{2}{*}{ Groups } & \multirow{2}{*}{$\begin{array}{l}\text { Oral dose } \\
(\mathrm{ml} / \mathrm{kg})\end{array}$} & \multicolumn{5}{|c|}{ Rectal body temperature ${ }^{\circ} \mathrm{F}$ at different hours (Mean \pm SEM) } \\
\hline & & Before $18 \mathrm{~h}$ & $\mathrm{Oh}$ & $1 \mathrm{~h}$ & $2 \mathrm{~h}$ & $3 \mathrm{~h}$ \\
\hline Control (DDW) & 10 & $98.6 \pm 0.12$ & $101.2 \pm 0.07$ & $101.2 \pm 0.04$ & $100.7 \pm 0.01$ & $100.4 \pm 0.01$ \\
\hline Paracetamol & 150 & $98.7 \pm 0.07$ & $101.5 \pm 0.04$ & $98.9 \pm 0.68$ & $98.60 \pm 0.44^{*}$ & $97.9 \pm 0.14^{*}$ \\
\hline EEPS & 500 & $98.9 \pm 0.23$ & $101.0 \pm 0.10$ & $98.9 \pm 0.10^{*}$ & $98.5 \pm 0.03^{*}$ & $97.6 \pm 0.14^{*}$ \\
\hline CEPS & 500 & $98.6 \pm 0.23$ & $101.2 \pm 0.08$ & $99.8 \pm 0.47^{\star}$ & $99.2 \pm 0.48^{\star}$ & $97.9 \pm 0.25^{*}$ \\
\hline NEPS & 500 & $98.9 \pm 0.53$ & $101.3 \pm 0.07$ & $98.6 \pm 0.13^{\star}$ & $97.9 \pm 0.13^{\star}$ & $97.6 \pm 0.17^{\star}$ \\
\hline
\end{tabular}

\section{Conclusion}

Data derived from our experiments suggest that EEPS, CEPS and NEPS have potential antioxidant, antiinflammatory, analgesic and antipyretic activities which are comparable with the standard drugs tested. Further research is required to identify chemical constituents, understand the underlying mechanisms and mode of action of the bio-active compounds.

\section{Acknowledgements}

The authors are thankful to the Department of Pharmacy, Southern University Bangladesh and the Institute of Biological Sciences, University of Rajshahi, Bangladesh for providing necessary laboratory and other facilities and to CHASA (Centre for Health Agriculture and Socio-economic Advancements) for providing funding and for technical assistance of this study.

\section{References}

Adams S, Hebborn, P and Nicholson S (1968). Some aspects of the pharmacology of ibufenac, a nonsteroidal antiinflammatory agent. J Pharm Pharma., 20(4): 305-312.

Ahmed A, Rajendaran K, Jaiswal D, Singh P, Mishra A, Chandra D, Yadav and Jain A (2010). Anti-snake venom activity of different extracts of Pouzolzia indica against Russel viper venom. Int. J. Chem Tech Res., 2: 744-751.

Bhal A, Bhal BS and Tuli GD (2003). Essentail Physical Chemistry. S Chand \& Co Ltd publishing, New Delhi., 680-681.

Chang T, Wu H, Wang Y, Kang P, Yang and Shyur F (2001). Antioxidant activity of extracts from Acacia confuses bark and heartwood. J. Agric Food Chem., 49(7): 3420-3424. 
Chanyapat S, Weena J, Yaowalak U and Tanawan K (2013). Antiproliferative Effect and the Isolated Compounds of Pouzolzia indica. Evidence-Based Complementary and Alternative Medicine, 1(1): 1-8.

Chi VV (1997). Dictionary of Vietnamese Medicinal Plants. Vol. 1. Hanoi: Medicine Publishing House. Ho Chi Minh City 210-215.

Collier J, Dinneen C, Johnson A and Scheider C (1968). The abdominal contraction response and its suppression by antinociceptive drugs in the mouse. Br. J. Pharmacol Chemother, 32(2): 295-310.

Dangol R and Gurung B (1991). Ethnobotany of the Tharu Tribe of Chitwan District, Nepal, Pharm. Biol., 29: 203-209.

De Pouzolz PMC (2012). Royal Botanist Garden, Index of Botanists. Havard University Herbarium Retrieved. http://purl.oclc.org/net/edu.harvard.huh/guid/uuid/5edbbb7c-062c.

Derardt R, Jougney S, Delevaliee F and Flahaut M (1980). Release of prostaglandins $E$ and $F$ in an algogenic reaction and its inhibition. European J Pharmacol., 61: 17-24.

Ghani A (2005). Practical Phytochemistry. 1st Ed., Parash Publishers, Dhaka, pp.12-8.

Grubben GJH and Denton OA (2004). Plant Research of Tropical Africa 2 Vegetables. PROTA foundation, Wageningen, Netherlands, pp. 430.

Hossain M, Islam M, Kalam Azad A, Abdullah Al Faruq A, Tareq S and Ahsan Q (2016). In vivo investigation of analgesic, antipyretic, antidiarrhoeal and anxiolytic activities of Blumea densiflora DC. European J Pharma. Medical Res., 3(11): 50-55.

Hossain MS, Rahman S, Rahmatullah AHM, Zaman A, Siddiky A, Mondal M, Huq T, B, Taslima Begum, Tabassum A, Alam S and Begum M (2016). Ethnopharmacological investigations of methanolic extract of $P$. zeylanica (L.) Clinical Phyto., 2: 2-10.

Ishfaq B, Dar A and Khan A (2004). Antinociceptive activity of methanolic extracts of St. John's Wort (Hypericum perforatum) preparation. Pak. J Pharm Sci., 17(2): 13-19.

Kravtsova TI, Friis I and Wilmot-Dear CM (2003). Morphology and anatomy of fruits in Pouzolzia (Urticaceae) in relation to taxonomy. Kew Bull., 58 (2): 297-327.

Merrill and Elmer D (1921). A bibliographic enumeration of Bornean plants. Journal of the Straits Branch of the Royal Asiatic Society, 84: 233.

Nhung M, Huong PTM, Anh NT, Tai BH, Nhiem NX, Doan VV, Hoang NH, Seo Y, Kim SH and Kiem PV (2020). Two new norlignans from the aerial parts of Pouzolzia sanguinea (Blume) Merr. Natural Product Research, 2 (1):1-8.

Patel R, Patel A, Desai S and Nagee A (2012). Study of secondary metabolites and antioxidant properties of leaves, stem and root among Hibiscus Rosasinensis cultivars. Asian Journal of Biological Experimental Sci., 3(4): 719-725.

Payum T, Das AK, Shankar R, Tamuly C and Hazarika M (2015). Antioxidant potential of Pouzolzia bennettiana-A nutritious traditional food plant used in Arunachal Pradesh, India. Advanced Journal of Pharmacy and Life Science Research, 3(2): 1-7.

Prasad K, Chandra D and Bisht G (2014). Evaluation of nutritive, antioxidant and mineral composition in wild edible rhizomes of Pouzolzia hirta Linn. Research, 8(1): 9-15.

Rabe T and Staden JV (1997). Antibacterial activity of South African plants used for medicinal purposes. J. Ethnopharmacol, 56: 81-87.

Sayeed A, Akteruzzaman M, Islam A and Sattar MA (2003). A prenylated isoflavone from Pouzolzia indica: it's in vitro antimicrobial activity and cytotoxicity evaluation. Oriental Journal of Chemistry, 19 (1): 35-40.

Shinde A, Phadke S, Nair M, Mungantiwar A, Dikshit J and Saraf O (1999). Membrane stabilizing activity-a possible mechanism of action for the anti-inflammatory activity of Cedrus deodara wood oil. Fitoterapia, 70: 251-257. 
Siriwatanametanon N, Fiebich L, Efferth T, Prieto M and Heinrich M (2010). Traditionally used Thai medicinal plants: in vitro anti-inflammatory, anticancer and antioxidant activities. J. Ethnopharmacol, 130: 196-207.

Srisapoomi T, Jiratchariyakul W, Partkaittikul N and Kummalue T (2008). Effect of two Thai herbal remedies on the sensitivity of chemotherapeutic agents in human cancer cells. Asian Journal of Traditional Medicines, 3(4):108-111.

Sulaiman R, Moin S, Alias A and Zakaria A (2008). Antinociceptive and anti-inflammatory effects of S. rhombifolia L., in the various animal models. Res. J. Pharma., 2: 13-16.

Sultana S, Faruq A, Nasim T and Ahsan Q (2018). In vitro anti-inflammatory, anti-oxidant and in vivo analgesic, antidiarrheal activities of fractional leaf extracts of Hibiscus surattensis. European $\mathrm{J}$ Pharmaceutical and Medical Research, 5(4): 167-173.

Upratya Y, Jiratchariyakul W and Kummalue T (2008). Anti-proliferative effects of Pouzolzia indica on acute promyelocytic cell lines: NB4 and HT93A. Asian Journal of Traditional Medicines, 3(4): 124-133.

Van Sam H, Baas P and Kebler A (2008). Traditional medicinal plants in Ben En National Park Vietnam. Blumea, 53 : 569-601.

Wagenen V, Larsen C, Cardellina R, Randazzo H, Lidert D and Swithenbank C (1993). Ulosantoin, a potent insecticide from the sponge Ulosa ruetzleri. Journal Org. Chem., 58: 335-337.

Wilmot-Dear CM and Friis I (2004). The old world species of Pouzolzia, A taxonomic revision. Nordic Journal of Botany, 24(1): 5-111.

Yadav K, Singh P, Jain A, Ahmed A and Indranil D (2012). In vitro antioxidant and radical scavenging activity of different extracts of Pouzolzia indica. Elixir Int. J., 47: 9143-9148.

Zimmermann M (1983). Ethical guidelines for investigations of experimental pain in conscious animals. Pain, 16(2): 109110.

(Manuscript received on 01 January 2021; revised on 18 May 2021) 